\title{
The American-Turkish Political Relations 1991-2001 A.D.
}

\author{
Ahmed Mahmood Alaw Al-Samarrae ${ }^{a}$, and Mohammad Hamzah Hussein ${ }^{b}$ \\ Asst.Prof. University of Samarra/ College of Education \\ ${ }^{\mathbf{b}}$ Asst.Prof. University of Al-Hamdaniya / College of Education
}

Article History: Received: 11 January 2021; Accepted: 27 February 2021; Published online: 5 April 2021

\begin{abstract}
The U.S. Turkish relations are one of the issues of interest to the researcher in the field of politics as it is a relationship between two important and active parties in the international arena, especially the Middle East region.

The United States had a great interest in Turkey's siding with the West. Turkey also found its interest in that, so we found it a member of the NATO.

In contrast to the expected after the collapse of the Soviet Union in 1991, Turkey's importance in the strategic perception of the United States did not end, especially since Turkey's geographical proximity seemed to be more strained and changing, not to mention the Western model adopted by Turkey, which the United States wants to be an example in the region. The American- Turkish relations for the period (1991-2001) were influenced by radical and fundamental changes. These variables are either internal or international. The internal factors influencing this relationship lie in the Turkish political parties which play a major role in the political process. The other factor is the Kurdish issue, which Turkey is dealing with very cautiously, while the United States has used it as a pressure card on the Turkish governments. It has not pursued a consistent policy on the issue and has always appeared against human
\end{abstract}

rights violations.

The other external factors, including the Cyprus issue, are a source of concern for the alliance strategy between the two countries from the 1960s until the present, and there is the matter of dealing with terrorism especially after the events of 11 September 2001.

The other factor is the question of the EU accession which is the Turkish dream and the source of interest for its foreign policy. Which the United States is trying to show that it is the only one who able to persuade the Europeans to accept the membership of Turkey.

Turkut Ouzel's government has sought to play a pivotal role at the regional and global levels and in the realization of Turkish interests in the Central Asian republics, the Black Sea basin, the Mediterranean basin, the Middle East region, the Arab neighbors, Israel, Iran and the Balkans, beside achieving the economic development and self-sufficiency; efforts are incessant to fulfill those ambitions.

Turkey has acted to change the unilateral approach towards the United States and the NATO to another one that includes multilateral policies related to the normalization of relations with the African and Asian worlds as well as neighboring countries.

Keywords: United States, American- Turkish relations, NATO, US strategy, Middle East.

\section{Introduction}

The US-Turkish relations are one of the issues of interest to the academic researcher concern, as it is a relationship between two important parties and a subject of attention to study the international political affairs in general and the Arab region in particular. Turkey has a very important geographical location and represents the link between the two continents of Asia and Europe, in addition to control the sea lanes and has borders with the Arab world. The Arab world is one of the most important strategic regions for the United States of America, which in turn has become a leader of the new international order and all countries of the world have become one of its elements, whether they want or not, even if that means interfering in its internal affairs.

The American-Turkish relations for the period (1991-2001 AD) were affected by the fundamental and radical changes. These variables either international, such as the collapse of the former Soviet Union in 1991, the crisis and the second Gulf war from 1990 to 1991 and ending with the events of September 11, 2001 AD, or internal, such as the Turkish voters' tendencies, represented in the radical shift from left to right party, which started to take place in the Turkish political scene with the growing feeling and religious tendencies.

The study was divided into a preface and two sections. The first section dealt with the (American-Turkish rapprochement towards common international issues). The second section dealt with the (US-Turkish relations under the new world order).

Preface

Since the end of the eighties and the beginning of the nineties of the twentieth century, the world witnessed many changes that signaled the receding of the storms of Cold War, in a way that made the world hopes vary between bright hopes and limitless disappointment. The communist regimes collapsed one after the other in Eastern Europe, and Berlin Wall collapsed in November 9, 1989. The former Soviet President and General Secretary of the Central Committee of the Communist Party, Mikhail Gorbachev (1985-1991 AD), undertook radical political reforms (perestroika and glasnost), and an era of cooperation between the two great powers began, as if a new era of peace and freedom was growing in the whole world (1). 
The world's hopes for the next few years have run into great disappointment, as the new democracies in Eastern Europe began to back down and suffered greatly from the problems of change. Gorbachev retracted his reforms, as the Balkans, Yugoslavia in particular, witnessed serious ethnic tension and appeared to be on the verge of wars threatening the whole of Europe. On the other hand, the world was surprised by a dangerous development in a sensitive region of the world represented by an Iraqi military invasion of the State of Kuwait on August 2, 1990, which resulted in what was termed in international relations "The Crisis and the Second Gulf War" (August 1990 - February 1991)(2). The Iraqi action meant that, according to American accounts, Iraq is controlling a large amount of the Arab Gulf oil. Nearly five months later, a most important event occurred which is the collapse of the former Soviet Union after the failure of the coup of the "New Bolsheviks" communists against Gorbachev on August 19, 1991, and the emergence of new countries following that collapse and disintegration. Some of these countries embraced huge reserves of natural resources and energy sources, especially those bordering the Caspian Sea, such as Azerbaijan (3).

Section One: American-Turkish rapprochement towards the common international issues

Turkey has benefited from international changes after the end of the Cold War, because it did not mean the disappearance of the Soviet threat and the establishment of a new world order, but it also meant reconsidering all of its external relations, especially the context on which its relations with the United States of America were based, which were based mainly on containing the Soviet threat. The vision seemed ambiguous with regard to the new framework for the relations of the two countries(4). On the one hand, there was a widespread belief between Turkish and foreign analysts at the time that Turkey faced a completely different foreign political and security environment from its counterpart that was prevalent no more than a decade ago(5). A lot of Turkish politicians were concerned and doubts about the role and location of their country in the new global and regional order, especially as the Europeans took more steps towards completing unity under the European Union, after the collapse of the Berlin Wall, the union that seemed as if it did not provide a place for Turkey(1). On the other hand, the Turkish President, Turgut Ozal, 1989-1993 AD, was looking at things differently, and considered the new changes that the world and the region witnessed from the end of the Cold War and its consequences as a set of opportunities if he exploited it in the best way, Turkey would turn to a global economic power and to change the prevailing impression of Turkey's security function only(3). He expressed that, in a speech to the first summit of the heads of the Turkish republics in Central Asia held in Ankara in October 30, 1992, saying: "... the Twenty first century will be the Turks Century". He felt that the time had come for Turkey to take its place among Advanced nations, and with the possibility of Turkey becoming "Japan of the Middle East"(5). Ozal expected that Turkey would play a pivotal role at the regional and global levels, and the possibility of achieving Turkish interests distributed in each of the Turkish Central Asian republics, the Black Sea basin, the Mediterranean basin and the Middle East where the Arab neighborhood is and (Israel), Iran and Balkans, and achieving economic development and self-sufficiency, but reaching all this requires achieving two basic things: first: create fundamental changes in internal politics from the social and economic aspects, second, and most important, because the success of the former depends on it, which is that the power and influence of Turkish diplomacy in international politics depends primarily on its ability to obtain support from the United States of America (6).

Turkey role during the nineties of the twentieth century is determined, from the perspective of the interests of the United States of America, in developing energy resources in Caspian Sea region, contributing in the development of the cooperation in the Black Sea basin and supporting modern independence countries in Central Asia in completing national independence and unity. As for the Middle East in containing both Iraq and Iran, developing strategic cooperation with Israel and in the Mediterranean basin, it has shown a willingness to establish stability and peace and resolve disputes with Greece. Turkey has also presented itself as a door to establish an edifice based on cooperation and advanced relations with Balkan countries, as well as their support for the process of establishing a new security architecture for Europe and for the expansion of NATO. Zbigniew Brzezinski, National Security Adviser during the reign of US President Jimmy Carter (1971-1974) and advisor to the Strategic and International Studies Center in Washington, classified Turkey as an important geopolitical country in the first place, along with Iran, as it preserves the stability of the Black Sea region, Russia's balance in the Caucasus, and benefits from being the southern haven of NATO, and it is possible that Turkey will turn into an unstable country that will unleash violence in the southern Balkans, While it is easy for Russia to impose its second control on the newly independent countries of Caucasus(7). Perhaps, the best evaluator of Turkey's position in the American strategic goals is Richard Holbrook, US Minister of Foreign Affairs Assistant of State for European Affairs and pioneer of the new concept of US-European relations, when he mentioned in the midnineties of the Twenty century that Turkey "plays an essential role ... to confront and contain Islamic fundamentalism (8).

The second Gulf War and Crisis 1990-1991AD revealed the strategic importance of Turkey's position to the western world in general and United States of America in particular. Turkey quickly took firmer and tougher stances when the UN Security Council adopted a series of binding decisions, including decisions 660 of August 2, 1990, and the decisions 661 in August 6, 1990, the first denounced the Iraqi measure and demanded that it withdraw immediately and unconditionally. The second imposed an economic embargo on Iraq. Turgut Ozal, in August 8, 1990, initiate to announce the suspension of the Iraqi oil lines passing through Turkey to the port of Ceyhan before the arrival of the US Secretary of State James Baker in Ankara at the same day(4).

There are many researchers who link Turgut Ozal's position in support of the Western alliance, led by the United States of America, to Turkey's commitment to NATO charters and the consistency of its policies with its 
strategies, and an expression of Ozal's enthusiasm personally in affirming Turkey's affiliation with the Western power (8).

Turgot Ozal practiced a distinguished diplomatic policy in dealing with the Kuwait crisis. He took the chance to respond to the opinion that Turkey lost its strategic importance to the West and United States of America, especially after the end of the Cold War and the emergence of a system led by the United States of America. This importance was derived mainly from Turkey role in the western endeavors to contain the influence of the former Soviet Union (9). It must be used and benefited to respond to the allegations of those views. Within the same context, Ali Bozer, the Turkish Foreign Minister, indicated that Turkey should take its rank and entitlements, and from this standpoint, Ozal traveled to Washington in October 15, 1990, when he met "G. Bush" (1989-1992 AD), and assured him that his country is a "strategic ally of the United States and a credible force in the Middle East", then he gave him details of the losses that Turkey would bear as a result of that. The American side promised him that he would take a share equivalent to his losses (10).

Ozal's expectations were correct. The United States of America realized once again the importance of the strategic benefit of Turkey to the western world, as the repercussions and results of the second Gulf War came to confirm its increasing importance for the United States of America. G. Bush remained in contact with Ankara throughout the time of the crisis (11).

Washington was quick to reward Turkey by raising the share of the Turkish textile exported to the American markets, and pledging to grant 1.4 billion in credits from the World Bank. As for the military aspect, it helped Turkey secure modern weapons worth $\$ 8$ billion, which were available to it as a result of disarmament in middle European. It was included 1,000 tanks, 700 armored carriers, a number of rocket-propelled grenades, and pledged not to cut US military assistance to Turkey under \$ 545 million annually (10).

The results of the second Gulf war and crisis quickly redefined Turkey's role and its strategic importance to the United States of America, and revealed the importance, inclusiveness and complexities of the Turkish role in the Middle East, as it made the United States of America considered it as a basic base for NATO and a basic home in the strategy that was known throughout the 1990s as a "dual containment" strategy in Confrontation Iraq and Iran(12). It encouraged the use of the increasingly importance role of Turkey in its regional planning and achieve coherent regional strategic goals. This position is perhaps best reflected in the statements of Martin Indeck, Assistant Secretary of State and the former Director of the Near East and South Asian Affairs at the US National Security Council, said: "Turkey is a secular state, democratic Islamic military and economic strength that has strategic location and an ally of the United States of America for a long time (9).

The adoption of a dual containment strategy by the President Bill Clinton's administration (1992-2000) as a way to deal with both Iran and Iraq, which described as threats to its interests in the Middle East, imposed Washington to encourage Turkey to be actively engaged in affairs of The Middle East and to work with the allies of the United States of America. Turkey had played a central role in containing Iraq by its commitment to the decisions of the United Nations and coordinating with it in implementing international sanctions imposed on Iraq (13). Turkey's importance has not been limited in its participation of allies to the war on Iraq and the implementation of the United Nations' decisions, but that role continued throughout the 1990s in the policy of containing Iraq. The success of the United States' policy towards Iraq was dependent on Turkey's response and cooperation with it, by forcing Iraq to implement Security Council resolutions and the terms of the ceasefire, as well as continuing the "Provide Comfort" process by establishing a safe haven for the Kurds of Iraq (12). This required obtaining Turkey's periodic approval to use the Turkish air bases in carrying out sorties to protect the Iraqi Kurds by the United States and its allies(3). Martin Indyk evaluated that role, in a speech to the Washington Institute for Near East Studies in May 18. 1993 AD, as he indicated that Turkey is of great importance in relation to our efforts to contain Iraq (6).

Turkey has adopted a less subordinate policy of the United States of America regarding Iran (1), and faced difficulties in implementing the policy of containing and isolating Iran in order to satisfy Washington, as it seemed as if Ankara was sometimes acting against American interests in its quest to maintain normal relations with Tehran, by using Iranian resources to meet the needs of Turkey's growing energy, and security issues of the two countries mainly related to the Kurdish issue in both countries and Iraq(5). All Turkish political forces call for the establishment of normal relations with Tehran, with the exception of the Turkish military, which is also another important gateway to the Central Asian region alongside the roads that cross the Caucasus countries. It is clear that all this contradicted the ongoing American efforts to isolate Tehran from the international political scene, but Washington's awareness of the need to maintain its alliance with Turkey in order to achieve wider strategic regional interests of the United States American, made the American politicians careful not to exaggerate the complaint and complain about Ankara's policy towards Iran (13).

It is worth noting that the United States of America maintains a good and developed level of relations with Turkey, since the latter's ability to build bridges of friendship with its regional environment which is important thing. The relations between its countries are friendly, and among countries that differ from them in terms of democracy, according to the vision of a senior American diplomat(14). One of the most important changes that occurred in Turkish foreign policy after the collapse of the former Soviet Union and the second Gulf War was the development of its relations with Israel. The Turkish-Israeli relations became more public in the nineties, and those relations developed rapidly until they reached an unprecedented degree by signing on the military cooperation agreement on 23 February 1996 (10). 
A researcher states that the goals and interests of the United States of America with the two new allies are focused on containing potential threats from Iran, Iraq and Syria, and limiting the spread of mass destruction weapon (15).

The early 1990s witnessed a great convergence in the American-Turkish view of the Madrid peace conference between the Palestinians and the Israelis in 1991 AD. Washington considered Turkey as an important pillar of the Arab-Israeli peace process(8), which would facilitate its plans in other parts of the world, such as Central Asia. The American ambassador in Turkey, Mark Crossman (1994-1997 AD), said: "We will expand our cooperation in regional issues in a way that makes Turkey an important party to the Middle East peace process (16).

Turgot Ozal was excited to participate in Madrid conference, and he reintroduced the idea of the Peace Pipeline Project in May 18, 1991, saying: "There is a water issue in Palestine, Israel, Jordan and the Arabian Peninsula, and Turkey is the only source of water in the Middle East, so this is why we called for the establishment of the Peace Pipeline Project" (6). The move was the subject of support and welcome from Washington, which urged that this relationship must be expanded to include another ally, Jordan, to serve as a model for the emergence of new alliances in the important regions in which the United States of America, according to its dominant role in its international relations, has the ability to effect the wider area where are those countries coexist (16).

The file of Turkish-Greek differences occupied a large portion of the United States of America interests. The American interests required the existence of Turkey and Greece as friends and they remain as strategic partners as allies of the United States of America and the West. The continuation of peace and the redrawing and building of the Balkan map depends mainly on the response of Athens and Ankara and they bear the brunt of the transformation of NATO's strategy toward the south. Also, both of them can contribute to the success of the US peace process in the Middle East, and they can turn into energy depots and important crossings to supply the European Union with energy resources from the Arabian Gulf and the Caspian Sea regions. The United States had considered both parties as an essential part in the construction of any "anti-defense" project for ballistic missiles against threats coming from the NATO's borders with the Middle East (2).

Although the negative impact of Turkish-Greek disputes remains on the development of US-Turkish relations and the outbreak of tension between Turkey and Greece during the 1990s. Washington had made great efforts in pursuing a policy of calm and balance far from bowing to Greek pressure groups within the US Congress, taking into consideration the growing strategic importance of Turkey within the framework of the American strategy. In this context, Washington managed to prevent any conflict from turning into serious Greek-Turkish military clashes, despite the complexity and depth of Turkish-Greek disputes, Washington's intense diplomacy managed to get the two parties to achieve a set of detailed agreements on seeking to settle their disputes peacefully. In this context, reference can be made to Washington's role in resolving the crisis of "Imia-Kardak" in 1995. The conflicting claims of the Turks and Greece, regarding the ownership the two islands, were about to turn into an imminent armed conflict between the two but intervention of US President Bill Clinton by phone, the attempts of some leading American politicians in Athens and Ankara, reinforced by diplomatic moves by NATO Secretary-General Javier Solana prevented thar (4)

As for the Cyprus issue, the United States of America aims in Cyprus was to establish two systems based on the existence of one state with two ethnic communities living in two regions, each with limited autonomy. The difference in that with Ankara's insistence on prior recognition of the Turkish Republic of Northern Cyprus, the dispute degree did not reach to a break, as the parties agreed to strengthen stability on the island. The United States of America prevented the delivery of Russian S-300 anti-aircraft missile systems to the Turkish Cypriots, which served as grounds for taking confidence-building between the Greek and Turkish Cypriots. It contributed greatly in improvement of the Greek-Turkish relations at the end of the nineties. The good impact of the contribution of Greece in providing relief to the victims of the 1999 earthquake in Turkey has contributed to the strengthening of that convergence. The improvement in their relations led to the removal of one of the main factors in the fluctuation of US-Turkish relations(7). This cooperation created a good effect in the American Congress, which issued a resolution in October 1999 showing sympathy for the earthquake victims in the two countries, and the decision appealed to them to exert greater efforts in resolving their deputes through discussion, as Congress has shown signs to withdrawing his objections on exporting weapons to Turkey (5).

As the Soviet Union fell apart, Turkey found itself facing a "new variable" in Central Asia, a world that it wanted to influence. The new republics were met with great enthusiasm and welcome from large sectors of the country's leads. A number of extremist milieus such as the MHP milieus have promoted many ideas and talk about the unity of the Turkish people led by Turkey, which will eventually become a political force capable of contributing to the process of shaping the new global order (9).

Suleyman Demirel (1993-2000AD) declared that “Turkey's readiness to take responsibility from the Adriatic to the Great Wall of China." (1). Turkey was one of the first countries to acknowledge the independence of those republics, and enthusiastically supported the new regimes in which it was established, as well in behalf of Georgia, Ukraine, Macedonia, and even Armenia, in an effort to prevent the rebuilding of the former Soviet Union, or any other form of a new Russian empire, fearing that the region would undergo a rapid and deep Islamization process at the hands of the "Iranian fundamentalism (11).

The United States of America quickly encouraged Ankara to seek a leadership role in the development of these newly independent republics. It promoted Turkey as a Western model against the Iranian model in relation 
to Central Asia, and a key factor helping to establish secular, pro-Western regimes in the former Soviet republics. Turkey has been enthusiastic about the new role, and has rushed to present itself as an official link between the new republics and the United States of America(14). Washington took the initiative to send (190) American students to learn the Turkish language in preparation for their use in various tasks in those republics (16).

Section Two: US-Turkish relations in light of the new global order

From an American perspective, the new world order meant the rearrangement of international issues as a result of the profound transformations that the world witnessed at the political and economic levels after the end of the Cold War and the disappearance of the polar conflict. As for the Balkans, the success of the new containment policy against Russia to prevent it from forming a new axis of international relations with the countries of warm waters. the purification of Balkans demand from the last cold war elites, represented by the Yugoslav Union, especially if this elite has an extreme nationalist tendency to politicize ethnic and religious tendency through the Slavic and Orthodox, and use it as a substitute for communism collapsed with the fall of the Soviet Union (17).

After the collapse of the Soviet Union the project of the United States of America and its western allies faced great challenges in Balkans, represented by the fragile situation in that region and the chaos that prevailed in Yugoslavia, which developed into violent ethnic conflicts. The result of which was the breakup of the Yugoslav Federation into more than entity accompanied by large-scale ethnic cleansing operations on the outskirts of the European Union. The United States of America, out of its strategic interests, found in its close ally "Turkey" one of the most important pillars and rules in peace and stability in Balkans and in maps' redraw, benefiting from Turkey's geographical location and its military bases in it, as well as in exploiting its religious and cultural relations with the peoples of the region from Muslims, as well as benefiting from its rank in the Islamic Conference Organization, to obtain support from its countries in curbing the Serbian regime led by Slobodan Milosevic 1987- 1997 (12).

Turkey's declared policy towards separated countries from Yugoslavia centered mainly on supporting the interests of the Muslims of the region and extending a helping hand to their brothers in religion and their partners in history. In August 1992, the Turkish Grand National Council demanded its government to take an attitude on Serbian policy based on the extermination of Muslims. It encroached that when Necmettin Erbakan, "the leader of the Al-Rafah Party," asked "Turkey to do in Bosnia what it had done in Cyprus before". the Turkish people began to be deeply indignant and skeptical against the Balkan Muslims (13).

In contrast to the angry reactions of the Turkish people, the Turkish government recognized the great difficulties faced in playing an important role in managing the Balkan crisis, due to Serbia's rejection of any Turkish role and the fear of politicians in Ankara of the Serbs accusing of declaring unilateral war on Belgrade(11). It was subjected to fierce criticism from Greece, and Serbia claimed that Turkey's attempt to reestablish itself as a dominant power in the Balkan Peninsula, leading to the revival of the Ottoman heritage in this region (15).

Turkey's role in managing the Bosnian war was formal, even within the activities of NATO, but the United States of America was convinced in the possibility of benefiting from a specific role for Turkey in ensuring stability in the Balkans, so it made Turkey as a crossing in order to provide Bosnian with weapons in light of the continued international embargo to supply weapons to Yugoslavia by making it the main partner in the "equipment and training" program launched by the US Department of Defense for the Bosnian Federation army. In accordance with that program, the United States of America provides military equipment and Turkey undertakes the training mission, according to which 300 Bosnian military personnel were dispatched monthly to Turkey for training. The US administration also asked Ankara to maintain its unit of 1,000 members within the 34,000 International Peacekeeping Force (SFOR) deployed in Bosnia (10).

The Dayton Agreement in January 14, 1995 to end Bosnian war did not succeed in normalizing the situation in Balkans and did not end the bloody war in it. The aforementioned agreement had not mention the "Kosovo province", which had an overwhelming Albanian majority, and witnessed violent clashes between the Serbian police, backed from the army, and the Albanian Kosovo Liberation Army KLA (18).

The United States of America supported the idea of direct military intervention in Kosovo and the destruction of Serbian infrastructure, not only in order to put an end to the Serbian racist behavior, and European concerns, but because the idea of intervention would have achieved a set of goals, the most important of which are: establishing a strategic base in Balkans that brings together the remaining Kosovo in terms of the twelve surrounding countries that NATO wanted to secure its destiny from Macedonia in the south to the group of Baltic states in the north on the borders of Russia to complete the policy of containment against the latter, and close its increasingly tight links with Russia (19).

NATO forces launched a series of air strikes from March 24 to June 1999, during which 15,000 raids were carried out over NATO countries, including 6000 raids on infrastructure and vital installations in Belgrade and the rest of the Serbian cities. As a result, it was forced to accept the recruitment of an international force to protect Population in Kosovo, and the establishment of a local administration in the province under the direct supervision and leadership of the United Nations (12).

From the beginning, Turkey supported the policy of the United States of America against Serbia and expressed its willingness to participate in any action against the latter. As the NATO started the attacks, Turkey has contributed eighteen F-16 jet fighters, and expressed its readiness to provide air bases for all NATO missions in Kosovo, and Participating with a thousand solder of its land forces in the accomplishment of the mission, but its recent desire was rejected by NATO due to opposition from Greece, and unlike all the allies of the United States 
of America from European countries, who wavered in the implementation of their obligations. Unlike all the allies of the United States of America from European countries, who wavered in the implementation of their obligations, Turkey accepted its share of 26 thousand eclipse refugees, and established refugee camps in Albania, Macedonia, on the border with Bulgaria. about 10 to 15 thousand others from the people of Kosovo, who had taken refuge in Turkey without complications, had been welcomed (20).

Turkey's effective participation in NATO operations in Kosovo had not been matched by planning for any prominent Turkish role in post-war missions. It had not been invited to participate in KFOR peace force, and there were no indication of any special Turkish participation in overall activities of the Eight Grand Groups. Although, the European powers were convinced that the peace process in Balkans would not be accomplished without Turkey's participation( ), at the same time they did not want to see the expansion of Turkey's influence and its return to the region. As for Turkey, it did not resort to an exaggeration in obtaining a large role in the region, and its position in a large part of that is due to the harmony of its foreign policy with its largest ally in NATO, the United States of America (12).

The United States of America considers Turkey as an ally, able to provide a great help to it in carrying out the missions of NATO and the United Nations, and in addressing the situations that threaten global peace and security, from its point of view. It was looking at Turkey as a country that possesses a huge human power and can send a huge amount of Humans. The American administration evaluation "least expensive role" that Turkey would play in relation to the United States of America based on "The presence of an American soldier in Turkey costs 90 thousand dollars annually, while the Turkish soldier costs only 16 thousand dollars annually". In front of this big difference in the cost between the American and Turkish soldier, the United States of America sought to assign the Turkish army many tasks in defending American interests, in return for undertaking the task of developing and strengthening the Turkish army, which means serving the interests of the United States of America (17).

Turkey's contributions to peacekeeping operations and the provision of humanitarian assistance, whether those led by NATO or the United Nations, were an appropriate opportunity to demonstrate the degree of US-Turkish military cooperation, as with "Providing Rest" process, April 1991, which provided protection to Kurds in northern Iraq and through participation in the efforts of the United States of America to restore peace and stability to Somalia in 1992, as the United Nations placed the forces there under the command of a Turkish general, as well as participating in the war on Yugoslavia, protecting Bosnia as mentioned above. The United States of America considered the importance of Turkey's contribution to these tasks, especially those that it led in Somalia in 1992 and Balkans in mid-nineties, as an indispensable partner within NATO. The participation of Turkish forces in NATO military missions in those areas was welcomed by the local population, especially in Somalia, Bosnia and Kosovo, as it was a clear and positive message to the entire Islamic world (21).

The manifestations of US-Turkish cooperation and partnership in nineties from the political and military aspects were largely reflected on the economic side. In 1993, the United States of America became Turkey's second largest trading partner, and the volume of trade exchanges between the two parties recorded a serious increase, especially after the meeting of Turkish Prime Minister Tansu Ciller(20) with Clinton in Washington in the end of 1993. They announced the formation of a special committee to develop relations and economic cooperation, and immediately after that in 1994 Washington included Turkey in the list of the ten best emerging economies in the world, to record the volume of trade exchange between the two parties during the years 19931997, an increase of $70 \%$ (21).

On the level of military relations, there was a great deal of development and prosperity. In April 1994, Assistant US Secretary of Defense Charles Freeman announced that "America will give Turkey a high priority to receive defense equipment" and "America has provided large quantities of weapons to Turkey, without imposing special restrictions, such as those imposed on all countries that receive weapons, and that there is no reason to change this position". He also declared that Turkey was given precedence to transfer American weapons in excess of their need, without putting conditions on their use(22). Despite the Congress, human rights organizations and groups pressure to impose Washington more restrictions on arms exports to Turkey, the United States of America continued to supply Turkey throughout the period 1993-2001 at a rate of 800 million dollars annually, and 99\% of weapons and military equipment and programs(20). The Turkish military establishment was the most enthusiastic about closer military relations with the United States American. "members of the American armed forces are comrades of arms, according to Turkish soldiers," according to the description of the Turkish Army Chief of Staff Ismail Hakki Qardai in the summer of 1998 AD. William Perry "Former US Secretary of Defense (1993-1997 AD)", Warren Christopher "Former US Secretary of State (1993-1997 AD)" and Madeleine Albright "former US Secretary of State" (1997-2001) agreed in that "Turkey is a decisive player" in "areas outside NATO missions", whether in bringing stability to Balkans or the Middle East and the Arabian Gulf (16).

The rapprochement achieved by the US-Turkish relations during the study period made Washington adopt a policy of double standards in a clear manner regarding many internal and external issues related to Turkey. The senior American politicians' statements reflected that duality, which showed the primacy of American strategic interests in their policies on considerations. On the other hand, US President Bill Clinton, who stated in May 1997 that: "Turkey, democratic, secular, stable and with a Western orientation, has always supported the efforts of the United States to enhance the factors of stability in Bosnia, and in newly-developed countries and we continue to support Turkey's effective and construction role in the framework of both NATO and Europe (21). 
In mid-November 1999, US President Bill Clinton made a diplomatic visit to Turkey lasted for five days, during which he spoke to various political elites in Turkey, and his most prominent talk was his speech to the Turkish Grand National Council in November 16, 1999, as he initiated it by saying: "The emergence of the Turkish Republic was one of the outstanding with which the twentieth century was formed, and the twenty-first century will be formed based on the developments taking place in Turkey and its surroundings (22).

\section{Conclusion:}

1. The United States had sought, through Turkey, to maintain the security of (Israel) in the region, because it saw Turkey and Israel as strategic allies to achieve its interests in the region.

2. Turkey sought to take advantage of regional and international changes after the collapse of the Iraqi forces after the first and second Gulf wars, to be the active state in cooperation with the Zionist entity in the region.

3. The United States of America saw the Turkish secular model as the optimal model for the regime in the region in order to counter the escalating Islamic revolutionary tide in it.

4. The United States of America aims to make Turkey a member of the European Union through the political pressure that Turkey can exert in favor of the United States of America in Europe.

5. The United States of America seeks to support Turkey economically and militarily in order to strengthen it on the regional countries, especially Syria and Iran, who saw Turkey as the implicit ally regarding the Iraqi file, especially the Kurdish issue.

\section{References}

1. Bayar M. Saef Al-Deen, The Kurdish question in American-Turkish relations 1991-1999, A thesis submitted, College of Education, University of Mosul, 2009, p. 37.

2. Mehmet Ali Tugtna, Turkish-Us security relations 1945-2003: Agame-theoretical analysis of the institutional effect, Doctor of Philosophy, Bogazici University, 2007, pp. 234-237.

3. Hakan Kantrci, Kisakactaki Bolge Kafkasya, IQ Kultur Sanat Yayincilik, Istanbul, 2006, SS. 111-125.

4. Soli Özel, "The Turkish-US Relationship in Historical Perspective", in: Bruce Maddy- Weitzman and Asher Susser (Ed), Turkish-Israeli Relations in a Trans-Atlantic Context Wider Europe and the Greater Middle East, The Moshe Dayan Center for Middle Eastern and African Studie, Tel Aviv, 2005, p. 110.

5. Simon V. Mayall, Turkey: Thwarted Ambition, Mcnair Paper, Institute for National Strategic Studies National Defense University Washington, DC, 1997, p. 56.

6. George S. Harris, U.S-Turkish relations, in: Alan Makovsky and Sabri Sayari (ed), Turkey's New World, Washington Institute for Near East Policy, Washington D.C, 2000, p. 198.

7. Omer Goksel Isyar, "An Analysis of Turkish- American relations from 1945 to 2004; inttiatives and reactions in Turkish foreign policy", Alternatives, Turkish Journal of International Relations, Vol.4, No.3, 2005, pp. 32-36.

8. Aylin Guney, "An Anatomy of the Transformation of the US-Turkish Alliance: From Cold War to War on Iraq", Journal of Turkish Studies, Vol. 6, No. 3, September, 2005, p. 345: William Hale, "Turkey, The middle East and Gulf Crisis", International Affairs, Vol. 68, No.4, October, 1992, pp. 683-687; Bayar M. Saef Aldeen, Op. Cit., p. 40.

9. F. Stephen Iarrabee, "Turkey ASA US. Security partner, Project air force, 2008, pp. 17-26.

10. The Objectives of United States Military Intervention in Northern Iraq Between Operation Eration Ration Desert Storm and Operation Iraqi Freedom, Michael A. Schies, A thesis presented to the Faculty of the U.S. Army Command and General Staff College in partial Fulfillment of the requirements for the Degree Master of Military art and Science General Studies, B.S., Missouri Western State College, Saint Joseph, Missouri, 1991. pp. 3-4.

11. Hasan Yilmaz, Turkey and The Middle East: Threats and Opportunities, Master Thesis of Arts in National Security Affairs from the Naval Postgraduate School, Monterey, California, 2001, pp. 143-149.

12. Ibid,P.43; Henri J. Barkey, Iran and Turkey: Confrontation across an Ideological Divide, in: Alvin Z. Rubinstein and Oles M. Smolansky (Ed), Regional Power rivalries in the new Eurasia: Russia, Turkey, and Iran, M.E. Sharpe. New York, London, 1995, p. 154.

13. Isa Afacan, Turkish-American relations in the post-cold war era 1990-2005, Doctor of Philosophy, Florida International University, 2011, pp. 68-81.

14. Bulant Aras, The Palestinian- Israel Peace Process in International Context with a Note on the Consequences for Turkish Foreign Policy, M. A. Thesis, Bogazici University, Istanbul, 2001, pp. 154-159; Bayar M. Saef Aldeen, Op. Cit., p. 40.

15. George E. Gruen, "Turkey and the Middle East after Oslo", in: Robert O. Freedman (ed), The Middle East and the Peace Process, The Impact of the Oslo, Baltimore Hebrew University, Florida, p. 202.

16. Kemal Krişci, "Turkey and United states: Ambivalent Alliance", Middle East Review of international Affairs, vd.2. No.4, December, 1998, p. 21; Bayar M. Saef Aldeen, Op. Cit., p. 40. 
17. Ian O. Lesser, "Turkey, Greece, and the U.S. In a Change Strategic Environment", Published by Rand, Santa Monica, 2001, pp. 5-9; Bayar M. Saef Aldeen, Op. Cit., p. 44.

18. Stephen j. Blank, "Turkey's Strategic Engagement in The Former Ussr and U.S. Interests in Stephen j. Blank and Others, Turkey's Strategic Position at Crossroad of World Affairs, Strategic Studies Institute, U.S., December, 1993, p. 69; Bayar M. Saef Aldeen, Op. Cit., p. 40.

19. Stephen j. Blank, "Turkey's Strategic Engagement in The Former Ussr and U.S. Interests in Stephen j. Blank and Others, Turkey's Strategic Position at Crossroad of World Affairs, Strategic Studies Institute, U.S., December, 1993, p. 69; Bayar M. Saef Aldeen, Op. Cit., p. 40.

20. Bayar M. Saef Aldeen,Op. Cit., p.45;Patricia M. Carley, "Turkey and Central Asia: Reality Comes Calling", in, Regional Power Rivalries IN THE New Eurasia, Russia, Turkey, and Iran Alvin Z. Rubinstein and Others (ed), M. E. Sharpe, New York, London,England,1995, p.194.

21. Stephen J. Blank and Others, Turkey and Europe: Expectations and Complications, in: William T. Johnson, Turkey's Strategic Position at the Crossroads of World Affairs, Strategic studies institute, U.S, 1993, pp. 1617.

22. John Murray Brown, "Tansu Çiller and the Question of Turkish Identify", World Policy Journal. Volume: 11. Issue: 3., U.S, 1994. pp. 56-60. 